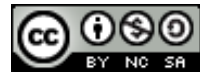

https://doi.org/10.31743/abmk.13193

ROBERT DEREWENDA* - LUBLIN

\title{
OPRACOWANIE, DIGITALIZACJA I UDOSTEPNIANIE FOTOGRAFII ZWIĄZANYCH Z DZIALALNOŚCIĄ KS. FRANCISZKA BLACHNICKIEGO W ARCHIWUM GŁÓWNYM RUCHU ŚWIATŁO-ŻYCIE
}

\begin{abstract}
Streszczenie
Fotografie dokumentujące działalność ks. Franciszka Blachnickiego zgromadzone w Archiwum Głównym Ruchu Światło-Życie to największe zbiory poświęcone tej osobie. Archiwum jest częścią Instytutu im. ks. Franciszka Blachnickiego, który zabezpiecza spuściznę po tym kapłanie i upowszechnia jego myśl. Na kolekcje fotografii składają się serie odbitek pozytywowych, slajdy, klisze oraz albumy. Zdjęcia zostały odpowiednio opisane i nadano im sygnatury. Fotografie, slajdy i klisze zostały zdigitalizowane w odpowiednich rozdzielczościach pozwalających na wykorzystanie do druku. Bezpośrednim dysponentem zdjęć jest Wydawnictwo Światło-Życie, które wydaje wiele książek poświęconych działalności ks. F. Blachnickiego. Fotografiami są również zainteresowane redakcje czasopism, portali internetowych i organizatorzy wydarzeń poświęconych ks. F. Blachnickiemu. Zdjęcia zostały również wykorzystane w przygotowaniu filmów o kapłanie. Założony przez ks. F. Blachnickiego Ruch Światło-Życie nieustannie się rozwija, a zainteresowanie osobą założyciela jest ciągle żywe.
\end{abstract}

Słowa kluczowe: ks. Franciszek Blachnicki; Archiwum Główne Ruchu Światło-Życie; dokumentacja nieaktowa; fotografie

$* * * * *$

We współczesnych czasach fotografia odgrywa coraz większą rolę w przekazywaniu informacji. Zdjęcie jest wizualnym śladem przeszłości i może oddziaływać na odbiorcę zarówno w sferze poznawczej, jak i estetyczno-emocjonalnej.

* Robert Derewenda - dr nauk humanistycznych w zakresie historii, asystent, Instytut Historii, Katolicki Uniwersytet Lubelski Jana Pawła II, dyrektor Instytutu im. ks. Franciszka Blachnickiego e-mail: robertderewenda@wp.pl

https://orcid.org/0000-0003-1096-5052 
Fotografie wzbogacają współczesną narrację historyczną na polu edukacyjnym oraz popularnonaukowym ${ }^{1}$. Obraz towarzyszy nam coraz częściej, a są kanały przekazywania informacji, takie jak np. popularne portale społecznościowe, które opierają się głównie na przekazie treści za pomocą obrazu² ${ }^{2}$ W ostatnich latach zaobserwowano w Archiwum Głównym Ruchu Światło-Życie coraz większe zainteresowanie zbiorami fotograficznymi kosztem kwerend dotyczących dokumentacji aktowej, a nawet dźwiękowej. Zainteresowanie dotyczy przede wszystkim fotografii związanych z życiem i działalnością ks. Franciszka Blachnickiego.

Archiwum Główne Ruchu Światło-Życie posiada największy zbiór fotografii dotyczący osoby ks. F. Blachnickiego. Archiwum jest działem Instytutu im. ks. Franciszka Blachnickiego, zgodnie ze swoim statutem zajmującym się zachowaniem spuścizny swojego patrona ${ }^{3}$. To statutowe zadanie instytucja ta realizuje w ramach działu, którym jest od 2001 r. archiwum Główne Ruchu Światło-Życie. Zajmuje się ono gromadzeniem, zabezpieczaniem i udostępnianiem dokumentacji związanej z życiem i działalnością ks. Franciszka Blachnickiego. Ponadto archiwum gromadzi dokumentację związaną z dziełami zainicjowanymi przez tego duchownego (m.in. dokumentacja Ruchu Światło-Życie, Krucjaty Wyzwolenia Człowieka, Krajowego Duszpasterstwa Służby Liturgicznej) ${ }^{4}$.

Wśród dokumentacji nieaktowej zgromadzonej w archiwum pokaźny zbiór stanowią nagrania i fotografie. Spośród tych ostatnich najbardziej interesujące z punktu widzenia historycznego są te związane z życiem i działalnością Sługi Bożego ks. F. Blachnickiego. Kapłan urodził się w 1921 r. w Rybniku. Wychował się na Górnym Śląsku i tam też mieszkał do wybuchu II wojny światowej ${ }^{5}$. Jako szeregowiec brał udział w kampanii wrześniowej. Uciekł z niemieckiej niewoli i zaangażował się w konspirację w Tarnowskich Górach. Aresztowany przez Niemców po przesłuchaniach w kwietniu 1940 r. został wywieziony do obozu koncentracyjnego w Auschwitz ${ }^{6}$. Stamtąd po czternastu miesiącach został przewieziony przez Niemców do Katowic, gdzie sąd wymierzył mu karę śmierci. Ostatecznie wyrok nie został wykonany, a F. Blachnicki do końca wojny był więziony przez Niemców w różnych obozach. W czasie oczekiwania na wykonanie wyroku śmierci nawrócił się. Po zakończeniu wojny wstąpił do seminarium? Święcenia kapłańskie otrzymał w 1950 r. W pierwszych latach swojej posługi duszpasterskiej skoncentrował się na pracy z ministrantami. Opracował dla nich system wychowawczy, którego niezwykle ważnym elementem były wakacyjne

\footnotetext{
${ }^{1}$ K. Napierała-Rydz, Fotografia w edukacji historii, w: Dziedzictwo audiowizualne $w$ warsztacie badawczym historyka i procesie dydaktycznym, red. R. Reczek, Poznań 2015, s. 213.

${ }^{2} \mathrm{~Np}$. Instagram lub Tik Tok.

${ }^{3}$ Statut Instytutu im. ks. F. Blachnickiego (oaza.pl), https://www.oaza.pl/statut-stowarzyszeniadiakonia-ruchu-swiatlo-zycie/ (dostęp: 12.10.2021).

${ }^{4}$ R. Derewenda, T. Nowicki, Archiwum Główne Ruchu Światto-Życie, „Archiwa, Biblioteki i Muzea Kościelne”, 99 (2013) s. 5-15.

${ }^{5}$ A. Wodarczyk, Prorok żywego Kościoła. Ks. Franciszek Blachnicki (1921-1987) - życie i działalność, Katowice 2008, s. 24-50.

${ }^{6}$ Tamże, s. 60-65.

${ }^{7}$ Tamże, s. 70-89.
} 
rekolekcje zamknięte: Oaza Dzieci Bożych ${ }^{8}$. W latach 1956-1960 rozwinął działalność ruchu trzeźwościowego pod nazwą Krucjata Wstrzemięźliwości. W sierpniu 1960 r. Centralę Krucjaty w Katowicach w brutalny sposób zamknęła Służba Bezpieczeństwa. Sam ks. F. Blachnicki w konsekwencji znalazł się na kilka miesięcy w areszcie w Katowicach. W 1961 r. rozpoczął studia na Katolickim Uniwersytecie Lubelskim ${ }^{9}$. Obronił licencjat, następnie doktorat, a w 1973 r. przyjęto jego pracę habilitacyjną. Władze państwowe jednak nie dopuściły do nadania mu stopnia. Na KUL pracował do 1976 r. ${ }^{10}$

Po soborze watykańskim II ks. F. Blachnicki zaangażował się we wprowadzanie odnowy liturgicznej w Polsce. W 1967 r. otrzymał nominację na Krajowego Duszpasterza Służby Ołtarza (później pod nazwą: Krajowe Duszpasterstwo Służby Liturgicznej) $)^{11}$. Funkcję pełnił aż do 1981 r. Od 1963 r. rozpoczął ponowne organizowanie oaz rekolekcyjnych w czasie wakacji. Początkowo dla młodzieży i kapłanów, a następnie dla innych grup: studentów, młodzieży pracującej, dzieci, nauczycieli i katechetów, a od 1973 r. dla całych rodzin. Tworząc trójstopniowy system formacyjny inicjowany na oazach, a kontynuowany w ciągu roku, utworzył struktury Ruchu Światło-Życie (w latach 1969-1976 pod nazwą Ruch Żywego Kościoła) ${ }^{12}$. W 1979 r. zainicjował działalność ruchu trzeźwościowego: Krucjata Wyzwolenia Człowieka. W 1980 r. rozpoczął realizację planu wielkiej ewangelizacji Ad Christum Redemptorem ${ }^{13}$. Jesienią 1981 r. zainicjował ruch społeczno-polityczny pod nazwą Chrześcijańska Służba Społeczna. Tuż przed wprowadzeniem stanu wojennego wyjechał z kraju. Na emigracji utworzył Międzynarodowe Centrum Ewangelizacji Światło-Życie w Carlsbergu w Republice Federalnej Niemiec. Rozszerzył działalność Chrześcijańskiej Służby Społecznej, tworząc Chrześcijańską Służbę Wyzwolenia Narodów. Podejmował szereg działań mających na celu wyzwolenie Europy Środkowo-Wschodniej spod systemu komunistycznego. Zmarł nagle 27 lutego 1987 r. ${ }^{14}$ Okoliczności jego śmierci pozostają niewyjaśnione do dziś ${ }^{15}$.

\footnotetext{
${ }^{8}$ R. Derewenda, Dzieło wiary. Historia Ruchu Światto-Życie 1950-1985, Kraków 2010, s. 17-26.

${ }^{9}$ Tamże, s. 27-49.

${ }^{10}$ Tamże, s. 57-58.

${ }^{11}$ Derewenda, Dzieło wiary, s. 69-71; T. Przybyła, Formacja ministrantów w ujęciu ks. Franciszka Blachnickiego, Kraków 2017, s. 87-106.

${ }^{12}$ Derewenda, Dzieto wiary, s. 59-65, 96-124.

${ }^{13}$ Tamże, s. 189-190.

${ }^{14}$ R. Derewenda, Działalność społeczna ks. Franciszka Blachnickiego, „Roczniki Humanistyczne", 63 (2015) z. 2, s. 230-233.

${ }^{15}$ Instytut Pamięci Narodowej w Katowicach prowadzi już drugie śledztwo w tej sprawie. Pierwsze zostało umorzone w 2006 r. Podjęcie na nowo śledztwa w sprawie zabójstwa ks. Franciszka Blachnickiego, Instytut Pamięci Narodowej, Komunikaty (ipn.gov.pl), https://ipn.gov.pl/pl/ dla-mediow/komunikaty/96933,Podjecie-na-nowo-sledztwa-w-sprawie-zabojstwa-ks-Franciszka -Blachnickiego.html (dostęp: 21.10.2021).
} 


\section{Zbiory fotografii w Archiwum Głównym Ruchu Światło-Życie zawierają- ce zdjęcia ilustrujące życie i działalność ks. Franciszka Blachnickiego}

Fotografie zgromadzone w Archiwum Głównym Ruchu Światło-Życie w Lublinie, zawierające omawianą tematykę, wchodzą w skład następujących zbiorów: fotografie zwykłe, fotografie carlsberskie, slajdy, negatywy, fotografie małe, fotografie duże, albumy fotograficzne, fotografie wykonane ze zbiorów specjalnych, fotografie podarowane.

Fotografie zwykłe to różnego formatu zdjęcia w formie wywołanych pozytywów bez zachowania negatywu. Najstarsze zdjęcia ilustrują czasy seminaryjne i pierwsze lata pracy ks. F. Blachnickiego. Jest to najliczniejszy zbiór fotografii w Archiwum. Najmłodsze pochodzą z pierwszych lat XXI wieku. Wraz z docierającymi do archiwum nowymi fotografiami w toku ich porządkowania do zespołu dołączane są kolejne fotografie. Są to zdjęcia ilustrujące genezę i historię rozwoju oaz oraz związanych z nimi dzieł na terenie Polski. Fotografie, na których został uwieczniony ks. F. Blachnicki oraz jego bezpośrednie otoczenie, znajdują się w seriach tematycznych do 1981 r. Zawierają 269 tematów, na które składa się obecnie 2745 fotografii ${ }^{16}$.

Fotografie z tego okresu w zdecydowanej większości są czarno-białe. Barwne stanowią jedynie ok. 5 procent. Najwięcej kolorowych odbitek pochodzi z lat 1979-1981. Są słabszej jakości niż fotografie czarno-białe. Ich kolory zostały często zdominowane czerwonym lub zielonym odcieniem ${ }^{17}$. Pierwsze zdjęcia barwne pochodzą z 1958 r., kolejne z 1968 r. $^{18}$. Kilka fotografii z lat 70. zostało wykonanych przez zagranicznych gości (w tym fotografie $\mathrm{z}$ aparatu polaroid) ${ }^{19}$.

Fotografie $\mathrm{w}$ tym zbiorze mają najczęściej format $10 \times 15 \mathrm{~cm}$ (format dominujący od połowy lat 70. XX wieku). Zdjęcia z lat 50. są jednak najczęściej mniejszego formatu (ok. $9 \times 6 \mathrm{~cm})$. Niemal wszystkie fotografie zostały wykonane na papierze błyszczącym.

${ }^{16}$ Archiwum Główne Ruchu Światło-Życie, zbiór: Fotografie zwykłe.

${ }^{17} \mathrm{~Np}$. AGRŚ-Ż, zbiór: Fotografie zwykłe, Dzień Wspólnoty w Wieczerniku im. Jana Pawła II. Krościenko nad Dunajcem 1979 r., sygn. 1979/12; tamże, Piąta Krajowa Kongregacja Odpowiedzialnych Ruchu Światło Życie. Jasna Góra 2.03.1980 r., sygn. 1980/1; tamże, Dzień Wspólnoty w Wieczerniku im. Jana Pawła II. Turnus III. Krościenko nad Dunajcem 1980 r., sygn. 1980/6; tamże, Oaza III stopnia w Rzymie, Rzym-Tivoli 1981 r., sygn. 1981/13.

${ }^{18}$ AGRŚ-Ż, zbiór: Fotografie zwykłe, Pierwsza Oaza Dzieci Bożych dla dziewczynek. Koniaków 1958 r., sygn. 1958/6. Trzy z siedmiu fotografii w tej serii są barwne. Jednocześnie są to najstarsze barwne fotografie w zasobie Archiwum. Przedstawiają ks. Franciszka Blachnickiego celebrującego Mszę świętą na łonie przyrody (w tle widać góry). Ciekawostką jest, że ks. Blachnicki odprawia Mszę przodem do wiernych. Jest to jednak okres jeszcze sprzed liturgicznej reformy soboru watykańskiego II. Jedna z fotografii została opublikowana w: R. Derewenda, Dzieło wiary, fotografia nr 13. Seria z roku 1968: AGRŚ-Ż, zbiór: fotografie zwykłe, Ks. F. Blachnicki z Zespołem Niepokalanej na schodach nowego domu przy ul. Armii Ludowej w Lublinie. 1968 r., sygn. 1968/1.

${ }^{19} \mathrm{~Np}$. AGRŚ-Ż, zbiór: Fotografie zwykłe, Ks. Franciszek Blachnicki i Krystyna Kegel. Centrum Ruchu Żywego Kościoła w Krościenku nad Dunajcem. 1973 r., sygn. 1973/3; tamże, Oaza Żywego Kościoła II turnus; Dzień Wspólnoty Oazy Wielkiej „Nowa Jerozolima” w Grywałdzie; tamże, Dzień Wspólnoty z kard. K. Wojtyłą. I turnus, Kluszkowce, 9.07.1978 r., sygn. 1978/6. 
Odrębną serię zdjęć stanowią fotografie ilustrujące działalność ks. F. Blachnickiego w Carlsbergu w RFN oraz w innych miejscach w latach 1982-1987. Jest to niewielka kolekcja obejmująca łącznie 88 odbitek pozytywowych $(28 \mathrm{z}$ nich to odbitki barwne) $)^{20}$.

Kolejny zbiór to slajdy, na które składa się 65 serii. Slajdy ilustrujące życie i działalność ks. F. Blachnickiego w Polsce to ok. 900 przeźroczy. Część z nich została podzielona na pojedyncze kadry i znajduje się w plastikowych kasetkach przygotowanych do prezentacji na rzutnikach przeźroczy, a część znajduje się na kliszach ciągłych ${ }^{21}$. Zwłaszcza slajdy z tych klisz są do dziś mało znane. Wszystkie slajdy są barwne i mają dobrze odwzorowane kolory. Jedyny mankament to zarysowania występujące na niektórych z nich. Po odpowiedniej obróbce komputerowej można jednak zniwelować istniejące rysy. Najliczniejszą serię wśród slajdów stanowią te wykonane przez jednego z moderatorów ruchu oazowego, ks. Huberta Lupę SVD. Na zdjęciach znajdują się obrazy prezentujące rozwój ruchu oazowego w latach 1972-197522. Z części slajdów na początku XXI wieku zostały wykonane fotografie. Do wykonania zdjęć konieczne było uprzednie sporządzenie negatywów, które jako sztucznie wywołany nośnik również zostały zachowane w archiwum. Procesowi uzyskania odbitek pozytywowych zostały poddane te slajdy, na których został uwieczniony ks. F. Blachnicki lub najważniejsze wydarzenia z historii Ruchu Światło-Życie.

W archiwum znajduje się również zbiór negatywów liczący 2498 kadrów, z tego 1728 wyłącznie na błonach fotograficznych, zaś 770 zeskanowanych bezpośrednio z klisz ${ }^{23}$. Spośród klisz zeskanowanych 13 pochodzi z czasów działalności ks. F. Blachnickiego w Polsce; zawierają one łącznie 366 fotografii. Najstarsze fotografie pochodzą z 1971 r., a najmłodsze z $1981^{24}$. Klisze są doskonałej jakości. Autor fotografii z tego okresu, ks. Józef Grygotowicz, jeden z moderatorów oazowych, dysponował wysokiej klasy aparatem fotograficznym. Zdjęcia posiadają ostry i dobrze naświetlony czarno-biały obraz. To właśnie wśród nich znalazły się serie z fotografiami ks. F. Blachnickiego i kardynała Karola Wojtyły odwiedzającego oazy ${ }^{25}$. Na początku XXI wieku 22 klisze zostały wywołane i zrobiono $\mathrm{z}$ nich odbitki fotograficzne, tworząc zbiór pod nazwą Fotografie małe ${ }^{26}$. Jednak, jak już zaznaczono wyżej, tylko $13 \mathrm{z}$ nich ukazuje ks. F. Blachnickiego lub działalność ruchu oazowego z okresu do $1981 \mathrm{r}$.

Fotografie wykonano również z części dużych klisz formatu $6 \times 6 \mathrm{~cm}$. Wywołaniu poddano 19 klisz z okresu działalności ks. Franciszka Blachnickiego. 189 fotografii kwadratowych kadrów uwiecznia okres od 1974 do 1979 r.. Na fotografiach znalazł się ks. F. Blachnicki i kard. K. Wojtyła podczas wydarzeń

\footnotetext{
${ }^{20}$ AGRŚ-Ż, zbiór: Fotografie carlsberskie.

${ }^{21}$ AGRŚ-Ż, zbiór: Slajdy.

${ }^{22}$ Tamże, seria: Slajdy ks. H. Lupy.

${ }^{23}$ AGRŻ-Ż, zbiór: Negatywy.

${ }^{24}$ Tamże, klisze nr 1-13.

${ }^{25}$ Tamże, klisze nr 1-2; 9-10.

${ }^{26}$ Tamże, zbiór: Fotografie małe.
} 
związanych z działalnością Ruchu Światło-Życie ${ }^{27}$. Jedna z klisz na barwnych fotografiach pokazuje Centrum Ruchu Światło-Życie oraz samo Krościenko nad Dunajcem, gdzie znajdowało się centrum ${ }^{28}$.

Kolejny zbiór fotografii stanowią albumy fotograficzne. Spośród tych, które zawierają zdjęcia z ks. F. Blachnickim, najcenniejszym jest jego osobisty album. Znajdują się tam zdjęcia z jego młodości: jako harcerza, ucznia, studenta czy żołnierza. Najmłodsze zdjęcia pochodzą z połowy lat 70. XX wieku. Łącznie album zawiera 54 fotografie ${ }^{29}$. Spośród innych albumów warto wskazać na utworzony w czasach zamieszkania ks. Franciszka Blachnickiego w Krościenku nad Dunajcem. Obejmuje okres od ok. 1971 do 1976 r. Zamieszczono w nim kadry przedstawiające najważniejsze miejsca na Kopiej Górce, dom Ruchu w Zakopanem oraz kościół w Brzegach. Na zdjęciach odnajdujemy m.in. ks. F. Blachnickiego, kard. K. Wojtyłę, ks. Wojciecha Danielskiego, współpracownika ks. F. Blachnickiego ${ }^{30}$. Część z fotografii jest powtórzeniem tych, które znajdują się w seriach zbioru Fotografie zwykłe. Dzięki temu łatwiej zidentyfikować kontekst (datę i wydarzenie) zdjęcia. Fotografie z ks. Blachnickim odnajdujemy również w albumie zatytułowanym Pielgrzymka Księży Polskich B. Więźniów Obozów Koncentracyjnych Gusen-Matthausen-Dachau 19 maja 1970 - 31 maja 1970 r. Oprócz kadrów ze szlaku po niemieckich obozach w albumie znalazły się również zdjęcia ze spotkania księży pielgrzymów z papieżem Pawłem VI w Watykanie ${ }^{31}$.

$\mathrm{Na}$ tym miejscu warto również wspomnieć o albumie, który wchodzi w skład zespołu aktowego. Album dokumentuje życie ministrantów i został osobiście przygotowany przez ks. F. Blachnickiego. Składa się z luźnych stron z fotografiami powtykanymi narożnikami w niewielkie nacięcia. Są one odręcznie podpisane przez tego kapłana odpowiednimi tytułami. Niektóre ze stron albumu zawierają tylko opis. Prawdopodobnie fotografie do danego opisu były dopiero planowane. Ze względu na formę przygotowania, jak również ścisły związek z pozostałymi aktami serii, którą duchowny sam oznaczył jako pedagogię ministrancką, album ze zdjęciami pozostawiono w ramach zespołu dokumentacji aktowej Ks. Franciszek Blachnicki ${ }^{32}$.

Unikatowy zbiór stanowi kilka fotografii wykonanych w formie skanów z fotografii z ramek z fotografiami znajdującymi się w pokoju ks. F. Blachnickiego w Krościenku nad Dunajcem oraz w innych ośrodkach Ruchu. Wśród nich znalazła się fotografia duchownego z KL Auschwitz, fotografia rodziców, fotografie ze spotkań z Janem Pawłem II. Te zdjęcia stanowią jedynie kopie elektroniczne (zeskanowane fotografie), poza cyfrową wersją nie mają fizycznego odpowiednika w zbiorach Archiwum.

${ }^{27}$ Tamże, zbiór: Fotografie duże.

${ }^{28}$ Tamże, sygn. D-1.

${ }^{29}$ AGRŚ-Ż, album ks. Franciszka Blachnickiego.

${ }^{30}$ Tamże, album z Krościenka.

${ }^{31}$ AGRŚ-Ż, album specjalny. Pielgrzymka Księży Polskich B. Więźniów Obozów Koncentracyjnych Gusen-Matthausen-Dachau. 19 maja 1970 - 31 maja 1970 roku.

${ }^{32}$ ASGRŚ-Ż, zbiór: Ks. F. Blachnicki, Teczka: Ministranci - życie scholii ministranckiej (2 poł. lat 50. XX w.), sygn. 00/17. 
Zbiory wzbogaca kilka serii fotografii podarowanych Archiwum przez osoby prywatne. Wśród nich znalazła się seria fotografii z pierwszych oaz organizowanych przez ks. F. Blachnickiego w latach 50. Została przesłana do archiwum przez Andrzeja Bulandę z Rybnika ${ }^{33}$. Inną serię tworzy przekazana przez Annę Jelinowską kolekcja 22 fotografii, na których znalazł się ks. Blachnicki w latach 70. XX wieku ${ }^{34}$.

\section{Opracowywanie fotografii}

Opracowanie fotografii związanych z życiem i działalnością ks. F. Blachnickiego rozpoczęło się wraz z utworzeniem Archiwum Głównego Ruchu Światło-Życie w 2001 r. Pierwszym procesem było scalenie fotografii pochodzących z różnych ośrodków Ruchu Światło-Życie ${ }^{35}$. Następnie poszczególne tematy fotografii ułożono w serie. Te zaś przyporządkowano do poszczególnych roczników. Fotografie trudne do zidentyfikowania zaliczono do wspólnych serii obejmujących poszczególne dekady XX wieku (lata: 40., 50., 60., 70., 80.). Następnie fotografie wypakowano z różnych pudełek, kopert, albumów i innych form przechowywania. Włożono je do specjalnie przygotowanych koszulek i wpięto do segregatorów. Każdy temat fotografii został opatrzony odpowiednim opisem. Składa się z następujących danych: nazwa zbioru, sygnatura, opis treści fotografii (tematu), data wydarzenia, imię i nazwisko autora fotografii, dane o negatywie, informacja o ewentualnych publikacjach fotografii, zabezpieczenie w formie elektronicznej, informacje o dacie opracowania i osobie opracowującej, uwagi.

Sam temat fotografii z reguły nie był trudny do ustalenia. Również główne postacie na fotografiach często udało się zidentyfikować. Przy ich identyfikacji pomocni byli bezpośredni świadkowie wydarzeń (przede wszystkim współpracownice ks. F. Blachnickiego z tzw. Zespołu Niepokalanej ${ }^{36}$ : Dorota Seweryn ${ }^{37}$,

${ }^{33}$ Niestety 158 fotografii zostało przekazanych do archiwum w formie kopii cyfrowych w rozdzielczości 72 dpi. AGRŚ-Ż, fotografie z oaz 1954-1957 Andrzeja Bulendy z Rybnika.

${ }^{34}$ Tamże, album Anny Salomei Jelinowskiej.

${ }^{35}$ Najwięcej pochodziło z ośrodka w Lublinie, gdzie zbierała je pierwsza Dyrektor Wydawnictwa Światło-Życie Grażyna Wilczyńska. Część pochodziła ze zbiorów w Centrum Ruchu Światło-Życie w Krościenku nad Dunajcem. Pojedyncze fotografie lub serie trafiały z innych ośrodków (np. z Krakowa) lub od osób prywatnych związanych z ruchem oazowym. Informacja własna autora, który od 2001 r. był pracownikiem AGRŚ-Ż w Lublinie.

${ }^{36}$ Dziś Instytut życia konsekrowanego: Instytut Niepokalanej Matki Kościoła.

${ }^{37}$ Jedna z najstarszych współpracownic ks. Blachnickiego, stała mieszkanka domu w Centrum Ruchu Światło-Życie w Krościenku od początku jego utworzenia w latach 60. XX wieku. Jej wspomnienia o współpracy z ks. F. Blachnickim zostały wydane drukiem: D. Seweryn, Nasze korzenie. Wspomnienia i świadectwo, Kraków 2019. O jej współpracy z ks. Blachnickim zob. G. M. Skop, Trzy opowiadania, jedna historia. O wspólnocie Niepokalanej i księdzu Blachnickim, Kraków 2018, s. 33-160. 
Zuzanna Podlewska ${ }^{38}$, Gizela Skop ${ }^{39}$ i Grażyna Wilczyńska ${ }^{40}$ ). Podczas rozmów ze świadkami część fotografii została fizycznie opisana na odwrocie pozytywu ${ }^{41}$.

Miejsce zarejestrowanej sytuacji najczęściej udało się ustalić. Przeważająca większość fotografii związana była z ośrodkami ruchu oazowego i miejscami działalności ks. F. Blachnickiego. Największą trudność sprawiało ustalenie dokładnej daty wydarzenia, które zostało zarejestrowane. Zwłaszcza niełatwo było ustalić datę $\mathrm{w}$ odniesieniu do wydarzeń, które odbywały się cyklicznie w tym samym miejscu, np. Dni Wspólnoty odbywane w latach 1972-1978 na Górze Błyszcz obok Tylmanowej. Organizowano je rokrocznie w każdym z trzech turnusów wakacyjnych. Inne tego typu wydarzenia w dziejach Ruchu Światło-Życie to powtarzalne od 1976 r. Krajowe Kongregacje Odpowiedzialnych (najczęściej na Jasnej Górze), organizowane od 1973 r. Centralne Oazy Matki (w Centrum Ruchu w Krościenku nad Dunajcem) czy też same wakacyjne rekolekcje oazowe organizowane na Podhalu co roku od lat 60.

Zbiór fotografii carlsberskich został oznaczony numeracją ciągłą od 1 do 87. Wśród nich nie oddzielono poszczególnych tematów. Podział na tematy został wprowadzony w większości slajdów. Tam również, tak jak w zbiorze Fotografie zwykłe, zastosowano numerację według poszczególnych roczników lub dekad. W ten sposób sygnatura składa się z następujących członów: rocznik, numer tematu w ramach rocznika, numer fotografii. Na przykład slajd przedstawiający ks. F. Blachnickiego sprawującego Mszę świętą podczas Dnia Wspólnoty oaz na górze Tabor 2 sierpnia $1971 \mathrm{r}$. ma sygnaturę 1971-1-66/67. Ostatni człon to numer przepisany z kliszy slajdu ${ }^{42}$. Wszystkie tematy slajdów posiadają analogiczny opis do zdjęć w zbiorze Fotografie zwykłe.

Zbiory z negatywami pozostawiono $\mathrm{w}$ ramach pierwotnie nadanych układów klisz. Błony fotograficzne jedynie ponumerowano, nadając im sygnaturę. W ten sposób niektóre serie (tematy fotografii) występują czasem na paru kliszach, a czasem jedna błona posiada kilka zarejestrowanych tematów. Również odbitki fotograficzne wykonywane $\mathrm{z}$ klisz odpowiadają swoją sygnaturą sygnaturze negatywu, z którego zostały wykonane. Fotografie wywołane z negatywów małych i dużych zostały opisane. Stworzono do nich odpowiednie inwentarze książkowe.

${ }^{38}$ Pierwsza Odpowiedzialna Główna Instytutu Niepokalanej Matki Kościoła (grupy dziewcząt współpracujących z ks. Blachnickim). O jej współpracy z ks. F. Blachnickim zob. Seweryn, Podlewska, Skop, Trzy opowiadania, s. 161-261.

${ }^{39}$ Jedna z najstarszych współpracownic ks. F. Blachnickiego. O jej współpracy z tym kapłanem zob. tamże, s. 271-326.

${ }^{40}$ Pierwsza dyrektor Wydawnictwa Światło-Życie wyznaczona do tej funkcji przez ks. F. Blachnickiego w 1978 r., zob. R. Derewenda, Działalność wydawnicza ks. Franciszka Blachnickiego w latach 1965-1981, „Pamięć i sprawiedliwość”, (2021) nr 1(37), s. 400. W latach 80. i 90. Grażyna Wilczyńska pieczołowicie zbierała fotografie, slajdy i negatywy związane z życiem i działalnością ks. F. Blachnickiego. Duża część zbiorów fotograficznych Archiwum pochodzi z tych kolekcji. G. Wilczyńska w latach 2001-2004 była pierwszą dyrektor Archiwum Głównego Ruchu Światło-Życie.

${ }^{41}$ Aby nie zniszczyć fotografii, wykorzystano miękkie ołówki 4B.

${ }^{42}$ AGRŚ-Ż, zbiór Slajdy, sygn. 1971-1-66/67. 
Znalazły się tam następujące dane: sygnatura, data wydarzenia, temat (wydarzenie: miejsce, okoliczności, osoby na fotografiach), autor fotografii, liczba klatek, typ negatywów, miejsce i sposób przechowywania ${ }^{43}$.

Albumy z fotografiami z ks. F. Blachnickim omówione powyżej podczas opracowywania pozostawiono $\mathrm{w}$ stanie pierwotnym.

\section{Digitalizacja fotografii}

Fotografie związane z działalnością ks. F. Blachnickiego zgromadzone w Archiwum Głównym Ruchu Światło-Życie bezpośrednio po uporządkowaniu zostały zdigitalizowane.

W procesie digitalizacji wykorzystano tradycyjne skanery płaskie. Fotografie zostały zeskanowane w rozdzielczości 600 dpi. W przypadku fotografii mniejszych niż $8 \times 13 \mathrm{~cm}$ skanowano je w rozdzielczości 1200 dpi, a najmniejsze fotografie (formatu legitymacyjnego) w rozdzielczości 2400 dpi. Taką rozdzielczość zastosowano również podczas skanowania slajdów i negatywów. W tym celu wykorzystano specjalny skaner do digitalizacji klisz i slajdów. Dzięki temu klisze, które znajdowały się w całych rolkach, pozostały w nienaruszonym stanie. Każda z klisz została po zeskanowaniu spakowana do własnej kasetki z opisem i sygnaturą. Wszystkie fotografie zapisano w formacie JPG bez kompresji.

Po zeskanowaniu serie fotografii zostały umieszczone w folderach, które otrzymały taką samą sygnaturę, jak seria fotografii. Każdej z fotografii przed zeskanowaniem nadano sygnaturę według wzoru omówionego powyżej. Sygnaturę naniesiono na odwrocie fotografii w lewym dolnym rogu. Identyfikacją każdej zeskanowanej fotografii jest właśnie jej sygnatura. Po zeskanowaniu we właściwościach każdej z fotografii wprowadzono opis znajdujący się fizycznie na fotografii. Przede wszystkim: temat fotografii (wydarzenie), osoby, miejsce i datę wydarzenia, autora fotografii.

Sam proces skanowania ${ }^{44}$ znacznie ułatwiał błyszczący papier, na którym zostały wykonane odbitki pozytywowe fotografii. Po zeskanowaniu fotografii na papierze matowym pozostała widoczna struktura papieru ${ }^{45}$.

\section{Udostępnianie fotografii}

Zainteresowanie zbiorami fotograficznymi związanymi z życiem i działalnością Sługi Bożego ks. F. Blachnickiego jest duże. Popularność kapłana wzrosła zwłaszcza w ostatnich latach. Powstały o nim trzy filmy. Do każdego z nich fotografie dostarczono właśnie z zasobu Archiwum Głównego Ruchu Światło-Życie $^{46}$. We wrześniu 2021 r. Panteon Górnośląski w Katowicach ogłosił konkurs

${ }^{43}$ AGRŚ-Ż, Inwentarz książkowy dla zbioru: Fotografie duże [b.m.w.]; tamże, Inwentarz książkowy dla zbioru: Fotografie małe [b.m.w.].

${ }^{44}$ Zob. Ilustracja nr 3, s. 65.

${ }^{45}$ AGRŚ-Ż, zbiór: Fotografie zwykłe, Wizyta ks. F. Blachnickiego w USA. Kwiecień 1978 r., sygn. 1978-3, fotografie $\mathrm{nr}$ 49-56.

${ }^{46}$ Pierwszy z nich to film Adama Kraśnickiego Prorok nie umiera - ks. Franciszek Blachnicki, nakręcony w 2016 r. Prorok nie umiera - ks. Franciszek Blachnicki (tvp.pl), https://katowice. 
na treatment filmu o ks. F. Blachnickim. Laureat konkursu podpisze z Panteonem umowę na napisanie scenariusza ${ }^{47}$.

Fotografiami są również zainteresowani komercyjni wydawcy książek i czasopism. Wiele artykułów o tym duchownym ukazuje się na łamach „Gościa Niedzielnego" i „Niedzieli”. Artykuły ilustrują fotografie z zasobu Archiwum Głównego Ruchu Światło-Życie ${ }^{48}$. Również inne portale, w tym PAP, informując o ks. F. Blachnickim, korzystają z fotografii z zasobu Archiwum ${ }^{49}$.

Pierwszym bezpośrednim korzystającym z zasobu fotograficznego Archiwum jest Wydawnictwo Światło-Życie ${ }^{50}$. To druga, obok Archiwum Głównego Ruchu Światło-Życie, komórka Instytutu im. ks. Franciszka Blachnickiego. Wydawnictwo Światło-Życie opracowuje i wydaje nie tylko materiały formacyjne dla ruchu oazowego, lecz także książki poświęcone samej osobie kapłana. Zdecydowana większość z konferencji i homilii wygłoszonych przez tego duchownego została wydana dopiero po jego śmierci. W Archiwum Głównym Ruchu Światło-Życie zachowało się kilkaset nagrań z konferencjami i homiliami ks. F. Blachnickiego. To właśnie one są podstawą do wydawania książek sygnowanych jego nazwiskiem. Na okładki tych książek trafiają i jako ilustracje wykorzystywane są zdjęcia z zasobu Archiwum ${ }^{51}$.

Wydawane są również dzieła wspomnieniowe o ks. F. Blachnickim, w których drukowanych jest wiele fotografii z zasobu Archiwum Głównego Ruchu Światło-Życie ${ }^{52}$. Najwięcej zdjęć zamieszczono w wydaniu albumowym biografii

tvp.pl/28038184/prorok-nie-umiera-ks-franciszek-blachnicki (dostęp: 21.10.2021). Film na płycie DVD został dołączony do „Biuletynu IPN” nr 9/2017. Kolejne dwa filmy zostały przygotowane w 2021 r. Reżyserem pierwszego, Blachnicki. Świadectwo Niepokornego, byli Jan Pospieszalski i Iwo Kardel. Film został wyemitowany w TVP1 24.03.2021 r. Film o księdzu Blachnickim w środę w TVP1 (dorzeczy.pl), https://dorzeczy.pl/obserwator-mediow/177008/film-o-ksiedzu-blachnickim -w-srode-w-tvp1.html (dostęp: 21.10.2021). Kolejny film przygotowany przez tych samych reżyserów został wyemitowany w listopadzie 2021 r. przez TVP1, TVP Historia i TVP Kultura. Blachnicki. Życie i światło, Vod.tvp.pl, Telewizja Polska S.A. (dostęp: 10.12.2021).

${ }^{47} \mathrm{~W}$ źródłach inspiracji wskazano m.in. zbiory Instytutu im. ks. Franciszka Blachnickiego. Konkurs na treatment filmu o ks. Franciszku Blachnickim (panteon-gornoslaski.pl), https://panteon-gornoslaski.pl/temat/2021/09/27/Konkurs-na-treatment-filmu-o-ks-Franciszku-Blachnickim (dostęp: 21.10.2021).

${ }^{48}$ Np. Prorok jedności (gosc.pl), https://www.gosc.pl/doc/7158474.Prorok-jednosci (dostęp: 21.10.2021).

${ }^{49}$ Np. Ks. Franciszek Blachnicki będzie bohaterem filmu fabularnego, dzieje.pl - Historia Polski (dostęp: 21.10.2021).

${ }^{50}$ Wydawnictwo Światto-Życie (wydawnictwo-oaza.pl) (dostęp: 6.10.2021).

${ }^{51}$ Np. F. Blachnicki, O małżeństwie i rodzinie, Kraków 2021; G. Wilczyńska, Wolny dla..., Kraków 2018; F. Blachnicki, Świadectwo niepokornego, Kraków 2012; tenże, Wielkich dziet Boga nie zapominajmy. Rola pamięci w życiu wewnętrznym i wspólnotowym, Kraków 2013; tenże, Życie swoje oddatem za Kościót, Kraków 2005.

${ }^{52}$ H. Bolczyk, Bliżej świętego. Moje spotkania z Czcigodnym Sluga Bożym ks. Franciszkiem Blachnickim, Katowice 2019; D. Seweryn, Nasze korzenie; Człowiek wiary konsekwentnej, Kraków 2021. W tej ostatniej pozycji zamieszczono 132 fotografie ze zbiorów Archiwum. 
duchownego Wychowawca wolnych ludzi $i^{53}$, wydanym w 2018 r. Autorka książki Grażyna Wilczyńska w 2019 r. otrzymała nawet wyróżnienie Feniks, przyznawane przez Stowarzyszenie Wydawców Katolickich. Książka została dostrzeżona w kategorii: Kościół wobec współczesności ${ }^{54}$. Fotografie zamieszczane są również w opracowaniach poświęconych działalności kapłana i są najczęściej wydawane przez Wydawnictwo Światło-Życie ${ }^{55}$. Zdjęcia ks. F. Blachnickiego cyklicznie zamieszczają na swoich łamach czasopisma oazowe, takie jak „Domowy Kościół”, „Eleuteria” czy „Życie w świetle”.

W 2017 r. przygotowano również wystawę Wychowawca wolnych ludzi, której która odbyła się w gmachu Sejmu $\mathrm{RP}^{56}$. Często zdigitalizowane fotografie ks. F. Blachnickiego są udostępniane różnym wspólnotom Ruchu Światło-Życie. Jest to związane $\mathrm{z}$ różnego rodzaju wydarzeniami przygotowanymi w poszczególnych wspólnotach. Fotografie są również prezentowane na wystawach, które tylko w części nawiązują do działalności kapłana ${ }^{57}$.

Spośród wszystkich kwerend przygotowywanych w Archiwum Głównym Ruchu Światło-Życie z fotografiami z ks. F. Blachnickim można wskazać kilka fotografii najbardziej popularnych. Pierwsza to niewątpliwie ta, na której duchowny został uwieczniony stojący, w berecie, z uniesioną głową. Fotografia została wykonana przez nieznanego autora 31 maja 1977 r. w Zakopanem ${ }^{58}$. Jest związana z poświęceniem kaplicy pw. Nawiedzenia NMP w domu Ruchu Światło-Życie w Zakopanem przy ul. Pardałówka $5^{59}$. Oprócz tego jednego zdjęcia w serii znajduje się jeszcze klika fotografii ks. F. Blachnickiego. Jednak właśnie to zdjęcie trafiło już na trzy okładki książek ${ }^{60}$, zostało wykorzystane jako główne zdjęcie na

${ }^{53}$ G. Wilczyńska, Wychowawca wolnych ludzi, Kraków 2018.

${ }^{54}$ Znamy laureatów Nagrody Feniks 2019, (Kai), https://www.ekai.pl/znamy-laureatow-nagrody-feniks-2019/ (dostęp: 06.10.2021).

${ }^{55}$ Derewenda, Dzieło wiary; Przybyła, Formacja ministrantów; H. Bolczyk, Wolny człowiekwolny naród. Ostatnie dzieło życia ks. Franciszka Blachnickiego: Chrześcijańska Stużba Wyzwolenia Narodów, Kraków 2012.

${ }^{56}$ Wychowawca wolnych ludzi (niedziela.pl), https://www.niedziela.pl/artykul/129972/nd/Wychowawca-wolnych-ludzi (dostęp: 06.10.2021).

${ }^{57} \mathrm{~Np}$. fotografie ilustrujące spotkania oazowe z udziałem ks. Blachnickiego i kardynała Wojtyły w 1974 r. zostały pokazane na wystawie Bracia w wierze. Wspótpraca katolików polskich $i$ słowackich w okresie komunizmu, przygotowanej w 2019 r. równoległe w dwóch wersjach językowych (polskiej i słowackiej) przez Instytut Pamięci Narodowej i słowacki Ústav pamäti národa, zob. Otwarcie wystawy „Bracia $w$ wierze. Wspólpraca katolików polskich i słowackich $w$ okresie komunizmu”, Warszawa, Instytut Pamięci Narodowej, Aktualności, 3.12 .2019 (ipn.gov.pl), https://ipn.gov.pl/pl/aktualnosci/83313,Otwarcie-wystawy-Bracia-w-wierze-Wspolpraca-katolikow-polskich-i-slowackich-w-ok.html (dostęp: 30.11.2021).

${ }^{58}$ Zob. Ilustracja nr 1, s. 64.

${ }^{59}$ AGRŚ-Ż, zbiór: Fotografie zwykłe, sygn. 1977-3-12.

${ }^{60}$ Odważny wiarą. Ks. Franciszek Blachnicki w naszej pamięci, oprac. G. Wilczyńska, Lublin 1992; Wodarczyk, Prorok żywego Kościoła; T.P. Terlikowski, Franciszek Blachnicki. Ksiądz, który zmienit Polskę, Kraków 2021. 
wystawie $\mathrm{i} w$ wielu artykułach poświęconych duchownemu ${ }^{61}$. Jest ono również dostępne w Wydawnictwie Światło-Życie w formie plakatu ${ }^{62}$. Fotografia stała się nawet inspiracją i wzorem obrazów ks. F. Blachnickiego, malowanych współcześnie na płótnie ${ }^{63}$.

Inną niezwykle popularną fotografią dość niespodziewanie została w ostatnich latach fotografia, na której duchowny wyraźnie wskazuje coś palcem. Zdjęcie zostało wykonane w marcu 1983 r. w Carlsbergu podczas spotkania polsko-ukraińskiego $^{64}$. Po pierwszym wykorzystaniu podczas sympozjum o ks. F. Blachnickim zorganizowanym w sejmie RP w 2017 r. zdjęcie szybko przypadło do gustu innym grafikom ${ }^{65}$. Dziś towarzyszy wielu wydarzeniom i artykułom poświęconym temu kapłanowi ${ }^{66}$.

Popularność tych fotografii możemy tłumaczyć ich wyrazistością i prawdopodobnie skojarzeniem obrazu z charakterem ks. F. Blachnickiego, który zapewne chcą przez zdjęcie ukazać graficy. Dawniej najczęściej wykorzystywanym zdjęciem z zasobu Archiwum było to, na którym duchowny w towarzystwie kard. K. Wojtyły i jego ówczesnego sekretarza, ks. Stanisława Dziwisza, wspina się na górę Błyszcz. Na szczycie 16 sierpnia 1972 r. Kardynał przewodniczył Mszy św. podczas Dnia Wspólnoty. Podczas Eucharystii zerwała się burza, a wśród siedmiuset osób znalazły się jedynie dwa parasole, które wystarczyły, by ochronić hostię. Niemal wszyscy uczestnicy przemokli do suchej nitki ${ }^{67}$. Wydarzenie było wielokrotnie wspominane zarówno przez oazowiczów, jak i przez papieża Jana Pawła II. Pięknie oprawione zdjęcie wręczyła delegacja Ruchu Światło-Życie

\footnotetext{
${ }^{61} \mathrm{~Np}$. Prokuratorzy IPN przeprowadzili ekshumację szczątów ks. Franciszka Blachnickiego, RadioMaryja.pl,https://www.radiomaryja.pl/kosciol/prokuratorzy-ipn-przeprowadzili-ekshumacje-szcza tkow-ks-franciszka-blachnickiego/ (dostęp: 22.10.2021); Prorok żywego Kościoła - ks. Blachnicki (gosc.pl), https://www.gosc.pl/doc/802249.Prorok-zywego-Kosciola-ks-Blachnicki (dostęp: 22.10.2021); Czcigodny Stuga Boży - Ksiądz Franciszek Blachnicki (panteon-gornoslaski.pl), https:// panteon-gornoslaski.pl/temat/2021/03/24/Czcigodny-Sluga-Bozy-Ksiadz-Franciszek-Blachnicki (dostęp: 22.10.2021). Fotografia została również wykorzystana w pierwszym klipie programu Ocaleni. Odcinek został poświęcony ks. Franciszkowi Blachnickiemu. Ocaleni, Vod.tvp.pl, Telewizja Polska S.A., 28.02.2019, https://vod.tvp.pl/video/ocaleni,28022019,41222544 (dostęp: 22.10.2022).

${ }^{62}$ Fotografia ks. Franciszka Blachnickiego - 1 (A3) (wydawnictwo-oaza.pl), https://wydawnictwo-oaza.pl/pl/o/fotografia-ks--franciszka-blachnickiego-914.html (dostęp: 22.10.2021).

${ }^{63}$ Obraz Zbigniewa Pieczyńskiego na okładce czasopisma „Domowy Kościół”, czerwiec-sierpień $2021 \mathrm{nr}$ 163, s. 1.

${ }^{64}$ AGRŚ-Ż, zbiór: Fotografie carlsberskie, sygn. 52.

${ }^{65}$ Wychowawca wolnych ludzi (oaza.pl), https://www.oaza.pl/wychowawca-wolnych-ludzi/ (dostęp: 22.10.2021).

${ }^{66} \mathrm{~Np}$. W Sejmie sympozjum i wystawa poświęcone ks. Blachnickiemu, twórcy Ruchu Światto-Życie (dzieje.pl - Historia Polski), https://dzieje.pl/aktualnosci/w-sejmie-sympozjum-i-wystawa-poswiecone-ks-blachnickiemu-tworcy-ruchu-swiatlo-zycie (dostęp: 22.10.2021); Druzgotanie bożków (gosc.pl), https://www.gosc.pl/doc/6753381.Druzgotanie-bozkow (dostęp: 22.10.2021); Prawda -Krzyż-Wyzwolenie, uroczysta gala Ruchu Światło-Życie, Radio Warszawa, https://radiowarszawa. com.pl/prawda-krzyz-wyzwolenie-uroczysta-gala-ruchu-swiatlo-zycie/ (dostęp: 22.10.2021).

${ }^{67}$ F. Blachnicki, Godziny Taboru, Kraków 2011, s. 26-28. Na okładce książki znalazł się fragment omawianego zdjęcia.
} 
ks. S. Dziwiszowi podczas spotkania z papieżem w Watykanie w 1998 r. Fotografia wywołała u Ojca św. wspomnienie wydarzenia i przypomniał delegacji, jak wtedy wszystkich zmoczył deszcz ${ }^{68}$.

Również zdjęcia całej postaci ks. F. Blachnickiego są współcześnie w zainteresowaniu korzystających z zasobu Archiwum. Takie ukazanie postaci jest chętnie wykorzystywane do przygotowania rolapów. Towarzyszą one różnym wydarzeniom Ruchu Światło-Życie ${ }^{69}$.

Niestety nie wszystkie kwestie prawne dotyczące praw autorskich do fotografii zgromadzonych w Archiwum zostały dostatecznie uregulowane. Większość autorów zdjęć jest nieznana. Trudno nawet ustalić, w jaki sposób fotografie trafiły do Ruchu Światło-Życie, a w konsekwencji do zasobu Archiwum Głównego Ruchu Światło-Życie. Jedynie zdjęcia przekazane przez ks. Józefa Grygotowicza, który jest autorem najliczniejszych ujęć z ks. F. Blachnickim, posiadają wyrażoną na piśmie zgodę autora na swobodne dysponowanie fotografiami przez Archiwum.

Podsumowując, warto zaznaczyć, że jest wiele czynników, które wpływają na zainteresowanie osobą ks. F. Blachnickiego. Jego działalność i myśl wykraczały poza czasy, w których żył i działał. Najlepszym dowodem jest ciągle rozwijający się, a założony przez niego Ruch Światło-Życie. Dzięki zbiorom fotograficznym, które zostały zdigitalizowane w Archiwum Głównym Ruchu Światło-Życie, wizerunki ks. F. Blachnickiego są powszechnie wykorzystywane i wzbogacają informacje o jego życiu.

\section{REFERENCES / BIBLIOGRAFIA}

\section{Źródla archiwalne}

Archiwum Główne Ruchu Światło-Życie w Lublinie

Dokumentacja aktowa

Zespół Ks. Franciszek Blachnicki.

Dokumentacja nieaktowa

Album Anny Salomei Jelinowskiej.

Album ks. Franciszka Blachnickiego.

Album specjalny. Pielgrzymka Księży Polskich B. Więźniów Obozów Koncentracyjnych Gusen-Matthausen-Dachau. 19 maja 1970 - 31 maja 1970 r.

Album z Krościenka.

Fotografie z oaz 1954-1957 Andrzeja Bulendy z Rybnika.

Zbiór: Fotografie duże.

Zbiór: Fotografie carlsberskie.

Zbiór: Fotografie małe.

Zbiór: Fotografie zwykłe.

${ }^{68}$ H. Bolczyk, Delegacja Ruchu Światto-Życie u Jana Pawła II, „Oaza. Pismo Ruchu Światło -Życie”, wrzesień-październik 1998 nr 34, s. 25-26.

${ }^{69} \mathrm{~Np}$. Moderator generalny Ruchu „Światto-Życie”: Właczamy się w Synod (gosc.pl), https://www.gosc.pl/doc/7189544.Moderator-generalny-Ruchu-Swiatlo-Zycie-Wlaczamy-sie-wSynod (dostęp: 23.10.2021). 
Zbiór: Negatywy.

Zbiór: Slajdy.

Pomoce archiwalne

Inwentarz książkowy dla zbioru: Fotografie duże [b.m.w.].

Inwentarz książkowy dla zbioru: Fotografie małe [b.m.w.].

\section{Źródła drukowane}

Blachnicki Franciszek, Godziny Taboru, Kraków 2011.

Blachnicki Franciszek, O matżeństwie i rodzinie, Kraków 2021.

Blachnicki Franciszek, Świadectwo niepokornego, Kraków 2012.

Blachnicki Franciszek, Wielkich dzieł boga nie zapominajmy. Rola pamięci $w$ życiu wewnętrznym $i$ wspólnotowym, Kraków 2013.

Blachnicki Franciszek, Życie swoje oddałem za Kościót, Kraków 2005.

Bolczyk Henryk, Bliżej świętego. Moje spotkania z Czcigodnym Stuga Bożym ks. Franciszkiem Blachnickim, Katowice 2019.

Bolczyk Henryk, Delegacja Ruchu Światło-Życie u Jana Pawła II, „Oaza. Pismo Ruchu Światło-Życie", wrzesień-październik 1998 nr 34, s. 25-26.

Człowiek wiary konsekwentnej. Ks. Franciszek Blachnicki 24 III 1921 - 27 II 1987, oprac. G. Wilczyńska, wyd. 2, Kraków 2021.

Odważny wiara. Ks. Franciszek Blachnicki w naszej pamięci, oprac. G. Wilczyńska, Lublin 1992.

Seweryn Dorota, Nasze korzenie. Wspomnienia i świadectwo, Kraków 2019.

Seweryn Dorota, Podlewska Zuzanna, Skop Gizela Maria, Trzy opowiadania, jedna historia. O wspólnocie Niepokalanej i księdzu Blachnickim, Kraków 2018.

Wilczyńska Grażyna, Wolny dla..., Kraków 2018.

\section{Prasa}

„Biuletyn IPN. Pismo o najnowszej historii Polski”, 2017 nr 9.

„Domowy Kościół. List do wspólnot rodzinnych”.

„Eleuteria. Kwartalnik Krucjaty Wyzwolenia Człowieka”.

„Życie w świetle” (czasopismo bez numeru ISSN wydawane w Międzynarodowym Centrum Ewangelizacji Ruchu Światło-Życie w Carlsbergu w RFN).

\section{Opracowania}

Bolczyk Henryk, Wolny człowiek - wolny naród. Ostatnie dzieło życia ks. Franciszka Blachnickiego: Chrześcijańska Stużba Wyzwolenia Narodów, Kraków 2012.

Derewenda Robert, Działalność społeczna ks. Franciszka Blachnickiego, „Roczniki Humanistyczne", 63 (2015) z. 2, s. 219-235.

Derewenda Robert, Działalność wydawnicza ks. Franciszka Blachnickiego w latach 1965 1981, „Pamięć i Sprawiedliwość”, 2021 nr 1 (37) s. 395-414.

Derewenda Robert, Nowicki Tomasz, Archiwum Główne Ruchu Światło-Życie, „Archiwa, Biblioteki i Muzea Kościelne”, 99 (2013) s. 5-17.

Przybyła Tomasz, Formacja ministrantów w ujęciu ks. Franciszka Blachnickiego, Kraków 2017.

Terlikowski Tomasz Piotr, Franciszek Blachnicki. Ksiadz, który zmienił Polskę, Kraków 2021.

Wilczyńska Grażyna, Wychowawca wolnych ludzi, Kraków 2018. 
Wodarczyk Adam, Prorok żywego Kościoła. Ks. Franciszek Blachnicki (1921-1987) życie i działalność, Katowice 2008.

Napierała-Rydz Katarzyna, Fotografia w edukacji historii, w: Dziedzictwo audiowizualne $w$ warsztacie badawczym historyka i procesie dydaktycznym, red. R. Reczek, Poznań 2015, s. 203-223.

\section{Netografia}

Prorok nie umiera - ks. Franciszek Blachnicki (tvp.pl), https://katowice.tvp.pl/28038184/ prorok-nie-umiera-ks-franciszek-blachnicki (dostęp: 21.10.2021).

Blachnicki. Życie i światło, Vod.tvp.pl, Telewizja Polska S.A., https://vod.tvp.pl/video/ blachnicki-zycie-i-swiatlo,blachnicki-zycie-i-swiatlo,57094721 (dostęp: 10.12.2021)

Czcigodny Stuga Boży - Ksiadz Franciszek Blachnicki (panteon-gornoslaski.pl), https:// panteon-gornoslaski.pl/temat/2021/03/24/Czcigodny-Sluga-Bozy-Ksiadz-Franciszek-Blachnicki (dostęp: 22.10.2021).

Druzgotanie bożków (gosc.pl), https://www.gosc.pl/doc/6753381.Druzgotanie-bozkow (dostęp: 22.10.2021).

Film o księdzu Blachnickim w środę w TVP1 (dorzeczy.pl), https://dorzeczy.pl/obserwator-mediow/177008/film-o-ksiedzu-blachnickim-w-srode-w-tvp1.html (dostęp: 21.10.2021).

Fotografia ks. Franciszka Blachnickiego - 1 (A3) (wydawnictwo-oaza.pl), https://wydawnictwo-oaza.pl/pl/o/fotografia-ks--franciszka-blachnickiego-914.html (dostęp: 22.10.2021).

Konkurs na treatment filmu o ks. Franciszku Blachnickim (panteon-gornoslaski.pl), https://panteon-gornoslaski.pl/temat/2021/09/27/Konkurs-na-tereatment-filmu-o-ks -Franciszku-Blachnickim (dostęp: 21.10.2021)

Ks. Franciszek Blachnicki będzie bohaterem filmu fabularnego, dzieje.pl - Historia Polski (dostęp: 21.10.2021).

Moderator generalny Ruchu ,Światto-Życie”: Włączamy się w Synod (gosc.pl), https:// www.gosc.pl/doc/7189544.Moderator-generalny-Ruchu-Swiatlo-Zycie-Wlaczamy -sie-w-Synod (dostęp: 23.10.2021).

Ocaleni, Vod.tvp.pl, Telewizja Polska S.A., 28.02.2019, https://vod.tvp.pl/video/ocaleni,28022019,41222544 (dostęp: 22.10.2021).

Otwarcie wystawy „Bracia w wierze. Wspótpraca katolików polskich i słowackich w okresie komunizmu”, Warszawa, Instytut Pamięci Narodowej, Aktualności, 3.12.2019 (ipn. gov.pl), https://ipn.gov.pl/pl/aktualnosci/83313, Otwarcie-wystawy-Bracia-w-wierze -Wspolpraca-katolikow-polskich-i-slowackich-w-ok.html (dostęp: 30.11.2021).

Podjęcie na nowo śledztwa w sprawie zabójstwa ks. Franciszka Blachnickiego, Instytut Pamięci Narodowej, Komunikaty (ipn.gov.pl), https://ipn.gov.pl/pl/dla-mediow/ komunikaty/96933,Podjecie-na-nowo-sledztwa-w-sprawie-zabojstwa-ks-Franciszka -Blachnickiego.html (dostęp: 21.10.2021).

Prawda-Krzyż-Wyzwolenie, uroczysta gala Ruchu Światto-Życie, Radio Warszawa, https://radiowarszawa.com.pl/prawda-krzyz-wyzwolenie-uroczysta-gala-ruchu-swiatlo-zycie/ (dostęp: 22.10.2021).

Prokuratorzy IPN przeprowadzili ekshumację szczątków ks. Franciszka Blachnickiego, RadioMaryja.pl, https://www.radiomaryja.pl/kosciol/prokuratorzy-ipn-przeprowadzili -ekshumacje-szczatkow-ks-franciszka-blachnickiego/ (dostęp: 22.10.2021).

Prorok jedności (gosc.pl), https://www.gosc.pl/doc/7158474.Prorok-jednosci (dostęp: 21.10.2021).

Prorok żywego Kościoła - ks. Blachnicki (gosc.pl), https://www.gosc.pl/doc/802249.Prorok-zywego-Kosciola-ks-Blachnicki (dostęp: 22.10.2021). 
Rybnik: młodzi przyszli na sympozjum o ks. Franciszku Blachnickim,| Dziennik Zachodni, https://dziennikzachodni.pl/rybnik-mlodzi-przyszli-na-sympozjum-o-ks-franciszku -blachnickim/ga/11917383/zd/23137739 (dostęp: 22.10.2021).

W Sejmie sympozjum i wystawa poświęcone ks. Blachnickiemu, twórcy Ruchu Światło -Życie, (dzieje.pl - Historia Polski), https://dzieje.pl/aktualnosci/w-sejmie-sympozjum-i-wystawa-poswiecone-ks-blachnickiemu-tworcy-ruchu-swiatlo-zycie (dostęp: 22.10.2021).

Wychowawca wolnych ludzi (niedziela.pl), https:/www.niedziela.pl/artykul/129972/nd/ Wychowawca-wolnych-ludzi (dostęp: 06.10.2021).

Wychowawca wolnych ludzi (oaza.pl), https://www.oaza.pl/wychowawca-wolnych-ludzi/ (dostęp: 22.10.2021).

Wydawnictwo Światło-Życie (wydawnictwo-oaza.pl), https://wydawnictwo-oaza.pl (dostęp: 06.10.2021).

Znamy laureatów Nagrody Feniks 2019, (Kai), https://www.ekai.pl/znamy-laureatow-nagrody-feniks-2019/ (dostęp: 06.10.2021).

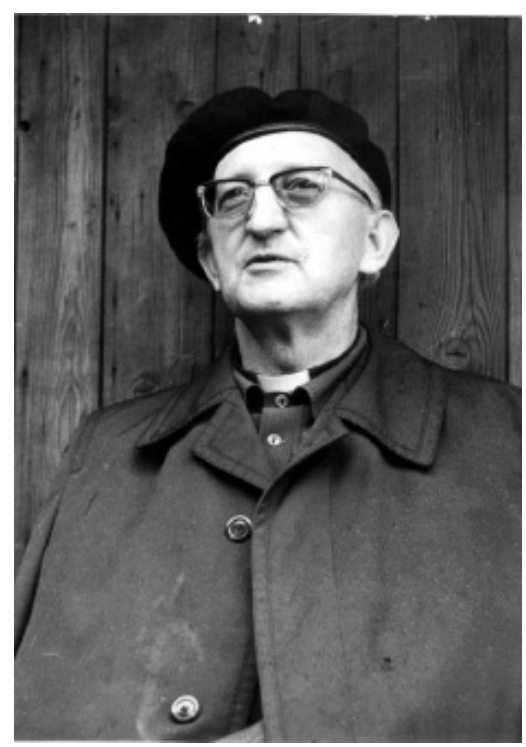

Il. 1. Ks. Franciszek Blachnicki w Zakopanem 31 maja 1977 r. Autor nieznany.

AGRŚ-Ż, zbiór: Fotografie zwykłe, sygn. 1977-3-12 


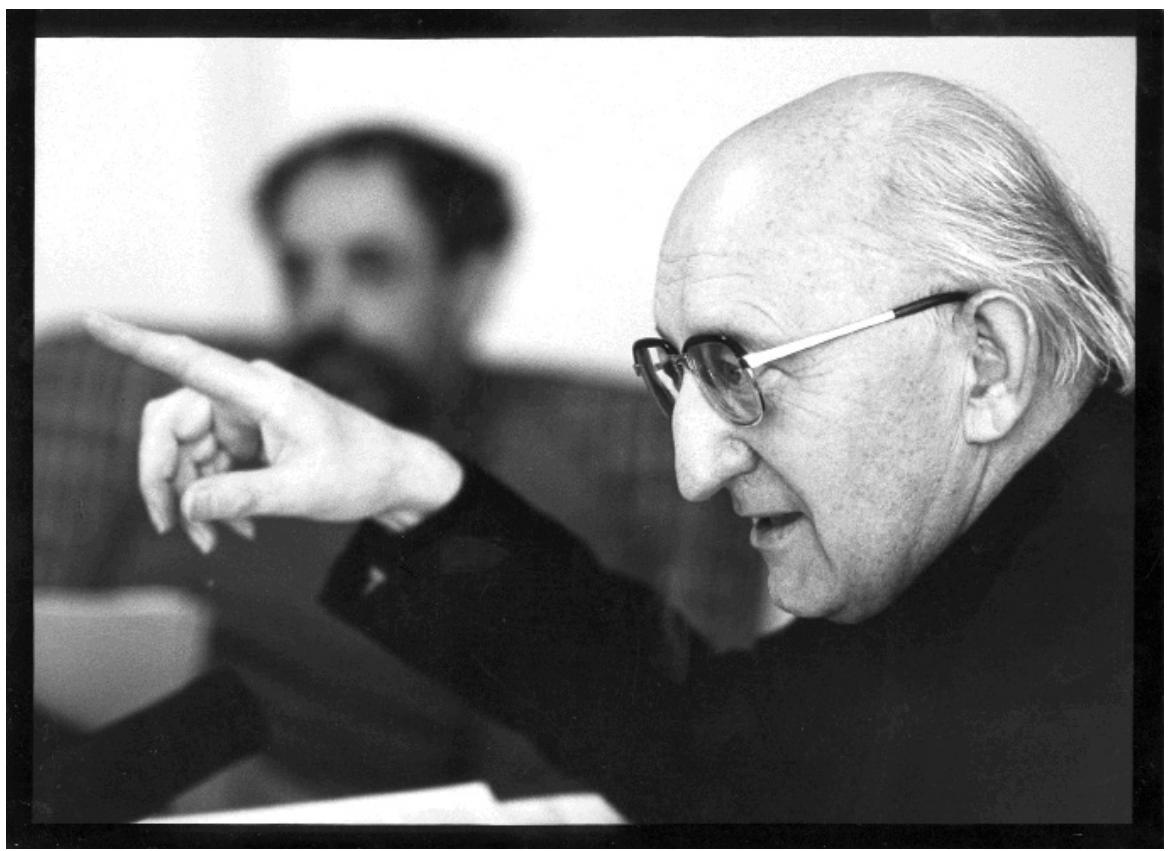

Il. 2. Ks. Franciszek Blachnicki podczas spotkania polsko-ukraińskiego w Carlsbergu w RFN w dniach 5 i 6 marca 1983 r. Autor nieznany. AGRŚ-Ż, zbiór: Fotografie carlsberskie, sygn. 52

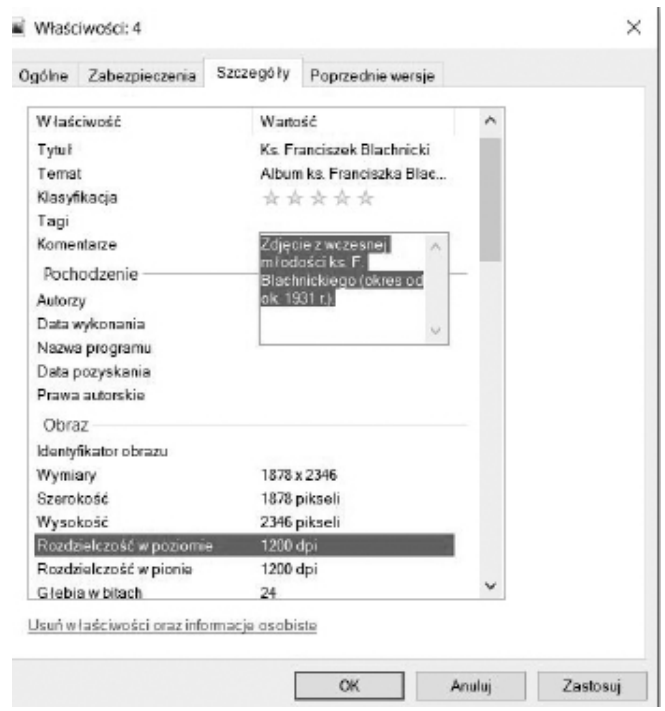

I1. 3. Opis (metadane) jednej z fotografii ( $\mathrm{nr}$ 4) z „Albumu ks. Franciszka Blachnickiego” 


\title{
DESCRIBING, DIGITALIZING AND MAKING AVAILABLE THE PHOTOGRAPHS RELATED TO REV. FRANCISZEK BLACHNICKI'S WORK IN THE CENTRAL ARCHIVES OF THE LIGHT-LIFE MOVEMENT
}

\begin{abstract}
The photograph collection illustrating the work of Rev. Franciszek Blachnicki accumulated in the Central Archives of the Light-Life Movement is the largest devoted to this person. The Archives is part of the Rev. Franciszek Blachnicki Institute, which preserves the legacy of Rev. Blachnicki and disseminates his thought. The collection of the photographs consists of a series of positive prints, slides, plates and albums. The photographs were arranged and appropriately described. Additionally, the photographs, slides and plates were digitised in a suitable resolution for printing. The direct holder of the collection is the Publishing House „Światło-Życie”, which have published numerous books on the work of Rev. Franciszek Blachnicki. Magazines, Internet portals and organisers of events devoted to Rev. Blachnick have also been interested in the collection. Furthermore, the photographs have been used in films about the priest. The Light-Life Movement founded by Rev. Blachnicki is constantly growing and the interest in its founder is still alive.
\end{abstract}

Keywords: Rev. Franciszek Blachnicki; the Central Archives of the Light-Life Movement; non-textual documentation; photographs 